\title{
コンクリート系建物の固有振動数の日変動メカニズムの解明 DIURNAL FLUCTUATION MECHANISM OF NATURAL FREQUENCIES OF A CONCRETE-MADE BUILDING
}

\author{
金澤 健 司*1 \\ Kenji KANAZAWA
}

\begin{abstract}
Diurnal fluctuations of natural frequencies are investigated from two-year ambient vibration test and model experiments with thermal loading, where a steel reinforced concrete building was seismically retrofitted on intermediate floors. The amplitudes of the diurnal fluctuations of the natural frequencies approach to $0.1 \mathrm{~Hz}$, which is of the same as the increasing due to the retrofitting works and that due to structural damage to be expected. The natural frequency fluctuations are strongly correlated with temperature differentials between the inside and the outside of outer columns or earthquake resisting-walls, that is also demonstrated by a concrete column test with thermal loading.
\end{abstract}

\section{Keywords: natural frequency, reinforced concrete building, thermal stress, ambient vibration, strucutral health monitoring 固有振動数，鉄筋コンクリート建物，温度応力，常時微動，構造ヘルスモニタリング}

\section{1 まえがき}

固有振動数や減衰定数などの建築物の振動特性は，個々の建築物 に固有の動的性状を表す基本的な指標である。近年，建築物の振動 特性が損傷によって変化する現象を利用して，振動特性の評価技術 を建築物の構造ヘルスモニタリングに応用するための研究が国内外 で盛んに実施されている122)3)。大地震の前後で建物の固有振動数 が低下する現象については，常時微動計測に基づく実建物での観測

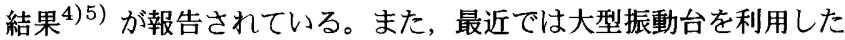
多層模型の損傷検出実験も試みられており，振動特性評価に基づく 構造ヘルスモニタリング技術を用いることで損傷検知が原理的に実 現可能なことが実証されつつある6)。

その一方で，実際の建物の固有振動数には，損傷とは無関係の変 動として, 従来から知られている振動振幅依存性 ${ }^{7)}$ による変動に加 えて，以下の述べるような日変動が含まれることが最近の観測事例 で明らかとなってきた。筆者らは，火力発電所に建設された高さ $200 \mathrm{~m}$ の鉄筋コンクリート造煙突を対象として，14日間にわたる常 時微動記録に基づいて固有振動数の経時変化を分析した結果，その 固有振動数の経時変化には日照や気温と相関する日変動が含まれる ことを見出した ${ }^{8)}$ 。詳細には，固有振動数の実測值は昼間に高く， 夜間に低くなる傾向にあり，この日変動を繰り返すこと，気温や日
照, 風力を入力とする煙突の伝熱解析と熱応力解析を実施した結果, 煙突壁面の表面温度差やその表面温度差に起因する熱応力の変動が 固有振動数の日変動と相関すること, 日照時間が長く，外気温の変 動が大きい日ほど固有振動数の日変動の幅が大きくなる傾向にある ことを確認した。このうち, 壁面の表面温度差と固有振動数の日変 動の関倸については，後日に温度と固有振動数の実測を実施し，伝 熱解析と熱応力解析に基づく考察が妥当であることを報告した ${ }^{9)}$ 。 さらに，筆者らは，本論文で対象とする鉄骨鉄筋コンクリート造 建物にも, 固有振動数が昼間に高くなる日変動が含まれ，その変動 幅は日照や外気温と相関することを確認した ${ }^{10)}$ 。建築物の固有振動 数と気温の相関性についてはClintonらによっても確認されており, 彼らは固有振動数の日変動がコンクリートの熱膨張に依存した現象 であることを予想している ${ }^{11)}$ 。温度や日照などの環境条件と固有振 動数の関係については，建築物とは構造形態や境界条件が異なる橋 梁構造物でも報告されている(2)13)14)。

以上のように，建物や橋梁などの大型構造物の固有振動数には, 損傷とは無関係な変動が含まれる場合がある。特に，気温や日照な どの環境条件に依存した固有振動数の日变動は恒常的に発生してお り,その変動幅が損傷に伴う変化量に対して無視できない大きさに 達することもあるため, 固有振動数は構造ヘルスモニタリングに倸

\footnotetext{
*1 電力中央研究所地球工学研究所 主任研究員 $\cdot$ 博士 (工学)

Research Engineer, Civil Engineering Research Laboratory, CRIEPI, Dr. Eng.
} 


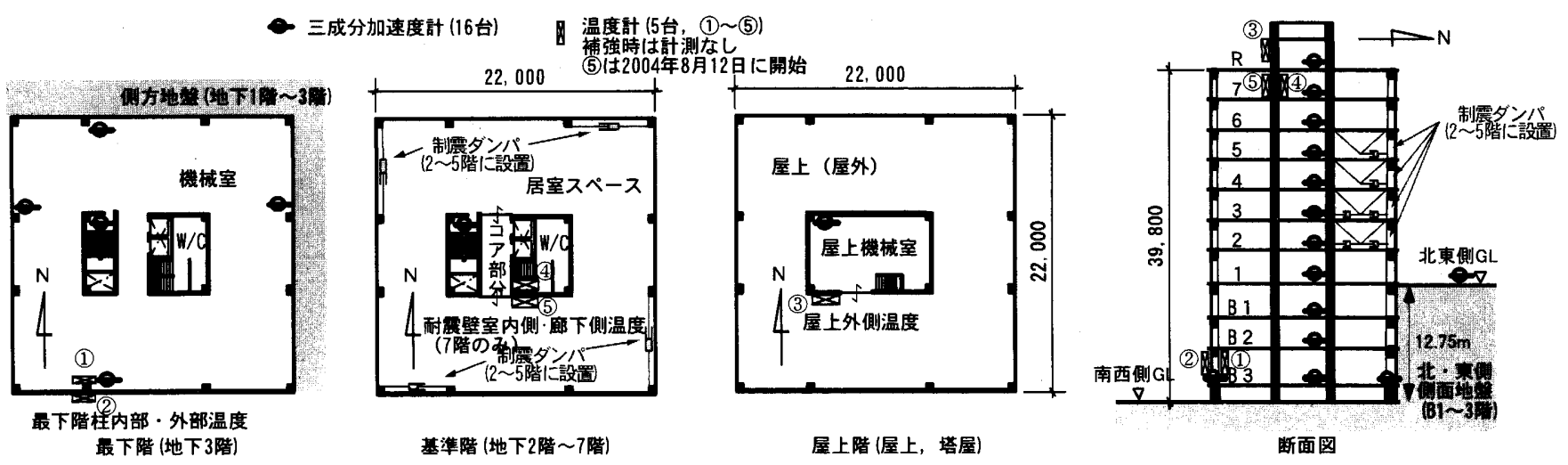

図 1 対象建物および計測点配置

わる損傷指標として信頼性を欠くとの指摘もある ${ }^{15)}$ 。この指摘は, 固有振動数を損傷指標とする場合だけでなく，応答観測波形から推 定される建物剛性などを損傷指標とする場合にもそのまま当てはま るといえる。このように, 固有振動数の日変動は, 振動特性や剖性 の推定値そのものを損傷指標した場合には誤差に相当するため, こ れを除去する立場での研究が必要となる。一方で, これとは対照的 な見方として，固有振動数の日変動が環境条件に依存した構造特性 の変化に起因するものであるならば，構造物に損傷や劣化などの不 具合が発生した場合には固有振動数の日変動の傾向にも変化が現れ ることも予想されて, 積極的に固有振動数の日変動現象を構造ヘルス モニタリングに取り入れていこうとする立場での研究も考えられる。

このような固有振動数の日変動による損傷評価の誤判定の対策や 有効活用を考えるためには, 固有振動数の長期モニタリングデータ やそれに基づく日変動メカニズムの解明が必要である。しかしなが ら, 構造物の振動デー夕を長期的かつ連続的に計測して振動性状を 継続的に調査した事例はほとんどなく, 固有振動数の日変動メカ二 ズムを解明する上でのデータの蓄積や知見はそしい。

本論文では，実建物の長期連続振動钼測とコンクリート試験柱の 部材実験の二通りの試験を実施して，建築物の固有振動数に日変動 が発生するメカ二ズムの解明を試みる。長期連続振動観測は，それ 自体が稀な試みであり椂々な不具合の発生が予想されたことから， 測定機器の点検の容易さを考慮して, 筆者の所属機関の建物を対象 とした。対象建物では，耐震補強工事が実施されており，その際に 計測した常時微動記録を用いて, 補強工事に伴う固有振動数の経時 変化をはじめに分析する。この分析を通して, 固有振動数の日変動 が構造ヘルスモニタリングで評価すべき変化量と比較して無視でき ない量に達することを述べる。次に，2003年12月から開始した長期 連続振動観測の記録を用いて，2006年1月までの約2年間にわたる固 有振動数の経時データを分析し，固有振動数の日变動が二種類の構 造部材の表面温度差に起因して発生している可能性があることを示 す。最後に，コンクリート試験柱に温度荷重を繰り返し作用させた 状態で固有振動数を経時的に測定し，その試験データに基づき対象 建物で観測された固有振動数の日変動がコンクリート部材の力学特 性によって説明できることを示す。

\section{2 建物概要}

対象建物は, 電力中央研究所我孫子地区南研究棟(千葉県我孫子 市)であり，1970年竣工の鉄骨鉄筋コンクリート造(SRC造)の10階
事務所ビルである。図1に断面図と平面図を示す。

本建物は南西傾斜面に建設されており，東面および北面の下部3 層はRC造土圧壁を介して側方地盤と接している。一方で, その反 対側の南面と西面は全層が地表に現れている。以下の記述では, 図1 の断面図に示すように，最下階を「地下3階」，東面ならびに北面の 地表レベルを「1階」，最上階を「7階」などと称する。

建設地盤は第二種地盤であり,アースドリル杭36本を支持杭(杭 先, 南側GL-27m) とする。対象建物から北へ100メートル程度離れ た位置に, 東西方向に国道6号線が通っており，この交通振動が対象 建物の常時微動応答の主要な振動源となっている ${ }^{16) 。}$

平面形状は, 図1の平面図に示すように $22 \mathrm{~m} \times 22 \mathrm{~m}$ の正方形であ り，中央コア部分に耐震壁を有するラーメン構造である。外周部の 柱は，最上階で $60 \times 60 \mathrm{~cm}$, 最下層で $90 \times 90 \mathrm{~cm}$ の断面を有し，外表 面は厚さ $2 \mathrm{~cm}$ の化粧モルタルの上に乳白色のアクリルペイントが厚 く塗布されている。一方で, 耐震壁の厚さは $35 \mathrm{~cm}$ である。また, 基 準階平面図に示すように，2001年の耐震補強工事によって，2階か ら5階には東西南北の各外側構面にオイルダンバとK型鉄骨ブレース から構成される制震装置が設置された。

各階の用途は, 最下階の大半が機械室, 地下 2 階から7階までが執 務室，屋上階のベントハウス部分が機械室となっている。このうち, 地下1階から7階までは，中央コアと外側に配置された居室スペース が自動扉で分けられており，各階の居室スペースは個別空調方式， 地下3階と中央コア内部が集中空調方式となっている。

\section{3 補強工團に伴う固有振動数の経時变化の評価}

\section{1 補強工事概要}

対象建物では2001年12月から2002年3月にかけて, 耐震性能を向 上させるための補強工事が実施された。補強方法は, 建物の 2 階から 5 階の中間階4層にオイルダンバによる制震装置を設置することで, 地震時の減衰性能の増加を図り, 建物全体の耐震性能を向上させよ うとするものである。

補強工事は鉄骨工事，コンクリート工事の後に，オイルダンバを 固定するという手順で実施された。鉄骨工事は，既設の柱および大 梁にアンカーボルトを打ち，K型鉄骨ブレースを組み上げてアン カーボルトに溶接するまでの工事である。一方で, コンクリートエ 事は，鉄骨ブレースのフレーム部と既設の柱・大梁の隙間をコンク リートで充填する工事である。以上の制震装置の設置工事を1階あた り4箇所(合計16籄所)で実施した。 
表 1 補強工事に伴う建物層㴊性の増加量(設計値)

\begin{tabular}{|c|c|c|c|c|}
\hline \multirow[b]{2}{*}{ 階 } & \multicolumn{2}{|c|}{ NS方向 } & \multicolumn{2}{|c|}{ EW方向 } \\
\hline & $\begin{array}{c}\text { 補強前剃性 } \\
{[\mathrm{kN} / \mathrm{cm}]}\end{array}$ & $\begin{array}{l}\text { 府加魝性 } \\
{[\mathrm{kN} / \mathrm{cm}]}\end{array}$ & $\begin{array}{l}\text { 補強前滆性 } \\
{[\mathrm{kN} / \mathrm{cm}]}\end{array}$ & $\begin{array}{l}\text { 付加㴊性 } \\
{[\mathrm{kN} / \mathrm{cm}]}\end{array}$ \\
\hline$\overline{\mathrm{PH} 2}$ & 2,299 & & 1,224 & \\
\hline PH1 & 3,042 & & 5,216 & \\
\hline 7 & 7,245 & & 11,917 & \\
\hline 6 & 9,756 & & 15,220 & \\
\hline 5 & 12,222 & $3,900(+24 \%)$ & 18,202 & $3,900(+18 \%)$ \\
\hline 4 & 15,053 & $3,900(+21 \%)$ & 21,550 & $3,900(+15 \%)$ \\
\hline 3 & 18,172 & $3,900(+18 \%)$ & 24,666 & $3,900(+14 \%)$ \\
\hline 2 & 22,242 & $3,900(+15 \%)$ & 28,659 & $3,900(+12 \%)$ \\
\hline 1 & 27,312 & & 36,065 & \\
\hline B1 & 56,633 & & 66,538 & \\
\hline B2 & 74,952 & & 79,801 & \\
\hline B3 & 109,104 & & 94,771 & \\
\hline
\end{tabular}

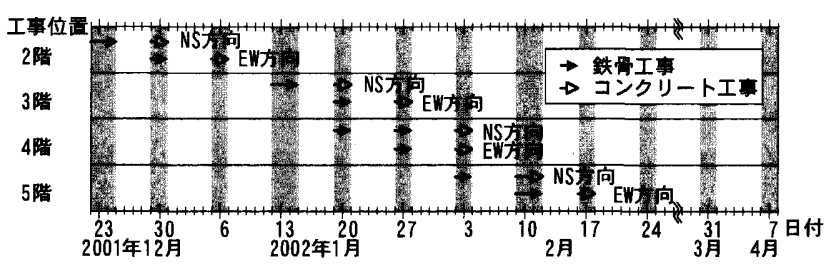

図 2 補強工事工程表

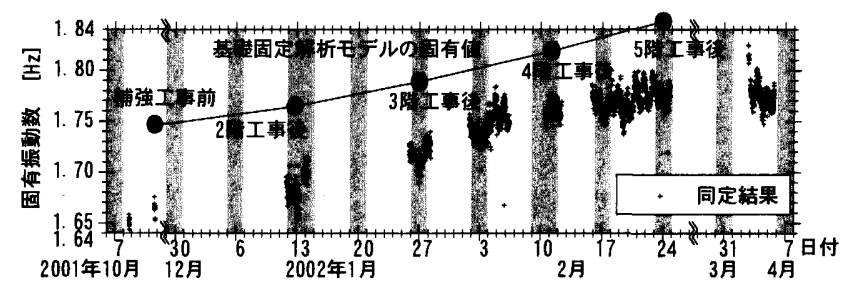

(a) NS方向 1 次固有振動数

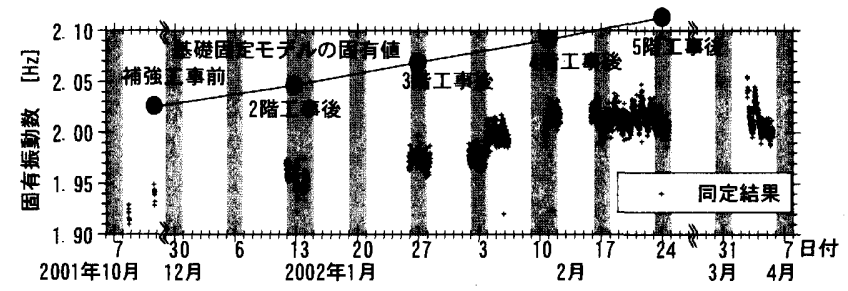

(b) EW方向1次固有振動数

図 3 補強工事の進展に伴う固有振動数の経時変化

図 2 に制震装置の設置工事の工程を示す。補強工事は建物を通常 通りに使用した状態で実施された。制震装置の設置工事のうち，建 物の剛性に影響を与える構造部材に係わる工事は，2001年12月 22 日 に開始され，2002年2月17日に終了した。これらの工事作業は騒音 や振動の恐れがあったため, 土曜日, 日曜日もしくは祝日の休日の みに限定して実施された。これら休日は，図2および図3において網 掛けで表記した。工事は，2階から始まり，3階，4階および5階と順 に上階に進むように実施された。

\section{2 各補強段階における建物の固有振動数の予測}

補強前の建物の設計資料から，建物の基礎部を完全固定とした多 質点せん断振動モデルと仮定した上で, 補強工事に伴う上部建物の みの1次固有振動数を解析的に予測した。表 1 に, 建設当時の設計図 面から計算した各階の層剛性と, 制震装置による付加剛性を示す。 ここで, 本論文では常時微動時の固有振動数を評価の対象としてお り, 微振動時には制震装置は剛性部材として作用するものと予想さ
れる。そこで, 表中の制震装置による付加剛性は，オイルダンパに よる稼動部を完全固定として計算した值を示した。補強前の建物の 層剛性が上階ほど小さくなることから, 制震装置の付加剛性の影響 は上階になるほど大きく, 層剛性の增加率は5階のNS方向(南北方 向)で $24 \%, \mathrm{EW}$ 方(東西方向)で $18 \%$ に達する。

実際の補強工事は図 2 に示すように各階の工事期間に多少の重複 があるが, 各補強段階における固有振動数は各階の工事が単独で順 に上階へと進展すると仮定して計算し, 後述の図3に各補強段階にお ける固有振動数の計算結果を実測値とともに併記した。各階の補強

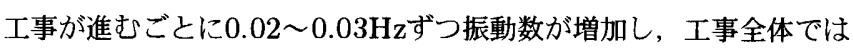
NS方向で $0.10 \mathrm{~Hz}, \mathrm{EW}$ 方向では $0.08 \mathrm{~Hz}$ 增加する。これを補強前後 の增加率で表すと, 各階の補強工事が進むごとに $1.0 \sim 1.7 \%$ ずつ振 動数が増加し, 工事全体ではNS方向で $5.5 \%, \mathrm{EW}$ 方向では $4.0 \%$ 増 加することになる。

\section{3 補強工事時の計測方法}

常時微動計測は, 補強工事前と各階の補強工事終了後に実施し た。補強工事前の計測は，2001年10月8日と11日に実施しており， 18 時から20時までの 2 時間の常時微動記録を得た。2階工事後および 3 階工事後の計測は 2002 年1月12日〜 14日および1月 26 日〜28日にそ れぞれ実施しており, 補強工事作業が実施されていない哚夜のみに 実施した。4階の補強工事以降(2月1日以降)は，補強工事作業が実施 されている休日昼間を含めて終日にわたり計測を実施した。建物構 造に影響を与える主要な補強工事作業は2月17日に終了しているが, その約 1 力月後の 4 月 2 日か 55 日の 3 日間には，全体の補強工事が終 了した後の計測を実施した。

計測には，16台の三成分加速度計(旧アカシ製JEP-6A3，過減 衰動コイル型 $2 \mathrm{G}$ 計), $24 \mathrm{BIT}$ A/D変換器(パベック電子開発製 DF-4000), 電圧増幅器(多摩テクニカル製DC05AB-16)を用いた。 加速度計の設置位置は, 前出の図1の断面図および平面図に示すよう に，各階の中央部分に1箇所ずつ計測点を設け，最下層である地下3 階にはロッキングによる基礎盤の上下運動を把握するために四隅に も計測点を設けた。さらに, 建物の北側地盤上(1階床レベル)にも加 速度計1台を設置した。観測量は加速度計16台の三成分であり, 合 計 48 成分である。計測条件は, 時間刻みを $200 \mathrm{~Hz}$, 加速度の測定範 囲を $\pm 25.6 \mathrm{~cm} / \mathrm{s}^{2}$ とした。なお, 補強工事時の計測では図 1 に示した 温度は計測していない。

\section{4 補強工事に伴う固有振動数の増加量と日変動の比較}

全ての常時微動記録を重複しないように15分ごとの小サンブル データに分割した後, それら小サンブルデータに対してARMAMA モデルによる振動モード同定法 ${ }^{17) 18)}$ を適用して, 15 分ごとの固有 值(固有振動数と減衰定数)の同定值を得た。同定法の適用にあたつ ては, 屋上と3階の二成分のクロススベクトルを推定することで固有 值を同定しており，小サンブルデータの時間刻みを $25 \mathrm{~Hz}$ で再サンブ リング(デシメーション)するとともに, ARMAMAモデルの次数を 20次, Yule-Walker方程式を解く際の特異值分解の閾值を $1 / 100$ に設定した。以上の方法で得られた固有值の同定值は, 地盤一構造 物系振動モデルのものとなる。図3に, NS方向およびEW方向の1次 固有振動数の同定値 $(+て ゙$ 表記) と基礎固定モデルの固有振動数(○で 表記;解析予測值と称する)を示す。 
$\mathrm{NS}$ 方向とEW方向の固有振動数の経時変化の傾向は類似してお り, 補強工事の進展とともに固有振動数の同定值が上昇していく傾 向が認められることや，その上昇していく傾きが解析予測値とほぼ 一致していることが確認できる。同定値は解析予測値を下回ってい るが，これは同定値が地盤一建物系の固有振動数を推定しているの に対して, 解析予測値が基礎固定の建物系の固有振動数を計算して いることによる。

その一方で，固有振動数の同定値には，測定時期に係わらず同定 值にばらつきが見られる。例えば，4階補強工事後の 2 月 16 日から 24日までの期間では, NS方向では1.73 1.80Hz, EW方向では 1.99 $2.05 \mathrm{~Hz}$ の範囲でばらついており，ばらつきの幅はそれぞれ $0.07 \mathrm{~Hz}$ と $0.06 \mathrm{~Hz}$ であり, 変動率で $3.9 \%$ と $3.0 \%$ に達する。これら のばらつきの幅は，固有値解析により予測した全補強工事に伴う固 有振動数の増加量に対して8割に達する数值であり, 補強工事による 固有振動数の増加量を同定值から判断する上で大きな誤差になると いえる。2月16日から24日までの固有振動数の同定值の経時変化を 詳細に見ると，1日を周期とする変動が認められ，この日変動がばら つきの主要な要因となっている。

以上のように，固有振動数の経時データからは補強工事の進展に 伴って固有振動数が増加する傾向を把握できるものの, 日変動によ るばらつきがあるために各補強段階における固有振動数の増加量を 評価することは難しい。設計值によれば，補強工事による5階の層剛 性は $18 \%$ もしくは $24 \%$ の增加となり，この增加量はかなり大きな岡 性変化であるといえる ${ }^{19)}$ 。構造ヘルスモニタリングの観点からは, 層剛性のこの程度の変化量は検出されるべきでありここで観測さ れた日変動幅は無視できない量に達しているといえる。

\section{4 固有振動数の長期要続モニタリング}

\section{1 計測方法}

前節において，固有振動数の経時変化には日変動が含まれ，その 日変動幅は構造ヘルスモニタリングにおいて評価すべき変化量と比 較して無視できない量に達することが判明した。そこで，固有振動 数に日変動が発生する要因を追究するため, 対象建物の長期連続振 動モニタリング（長期観測）を試夕た。長期観測は，2003年12月15 日から開始して2006年6月現在も継続中であり，2〜3ヶ月ごとに実 施されるデー夕の回収作業時間(1〜2時間程度)を除いた連続記録を 取得している。観測デー夕の時間刻みは，2004年7月13日までは $50 \mathrm{~Hz} ， 8$ 月23日までは60Hzであり，それ以降は120Hzに固定した。 本論文では，2006年1月27日までの約2年1ヶ月間の記録を用いて固 有振動数の経時変動を分析する。

観測量は，図1に示す通りであり，建物各階中央部の水平二成分 の加速度 $(22$ 成分), 屋上階之地下 3 階四隅の上下加速度 (5成分), 建 物の主要構造部材の表面温度(5成分)の合計 32 成分である。このう ち, 加速度の計測条件は計測範囲 $\pm 256 \mathrm{~cm} / \mathrm{s}^{2}$, 分解能 $24 \mathrm{Bit}$ であ り, 中小地震から常時微動の振動デー夕を収録した。一方で，建物 温度は, 建物の主要な構造部材である外周柱と中央コア部分の耐震 壁に着目して，地下3階南外周柱の内外表面(図中(1)と(2))と屋上ペン トハウス(PH)の南壁面の外表面(図中(3))，ならびに7階南側耐震壁 の廊下側(図中(4);中央コア内側)と室内側(図中(5; 中央コア外側)に設 置した。なお，建物外表面の温度を地下3階南外周柱(1)とPH南壁面
(3)の二箇所で測定した理由は，冬季には建物下側が午後の早い時間 に周辺の樹木の陰になり, 地下3階南外周柱(1)の温度計では建物の南 面外側温度の代表点になりえないと考えたためである。また，7階南 側耐震壁の室内側(5)の温度計は他の温度計よりも計測の開始時期が 遅れており，2004年8月12日から計測を開始した。

\section{2 固有振動数の年間変動}

\section{(1)固有振動数の評価方法}

固有值の同定は前節と同様の手順および条件で実施しており，全 観測記録を重複しないように15分ごとの小サンプルデータに分割し た後，それぞれの小サンプルデータに対してARMAMAモデルによ る振動モード同定法を適用して，15分ごとの固有振動数と減衰定数 を得た。観測記録の大半は屋上と 3 階の記録のクロススベクトルに よって固有值を同定した。しかし，2004年5月19日から6月16日ま での期間に関しては, 計測機器の不具合により屋上の記録が得られ なかったため，3階のバワースベクトルをARMAモデルで推定する ことで, 固有值を同定した。

以上の手順により同定した固有振動数と屋上の最大加速度を図 4 に示す。ここで, 図4-(c)では, 屋上の水平成分のいずれかの最大加 速度が $1 \mathrm{~cm} / \mathrm{s}^{2}(=\mathrm{gal})$ を超過した記録の最大值のみをグラフ上にプ ロットしており，さらに $50 \mathrm{~cm} / \mathrm{s}^{2}$ を超過した記録には印と番号を 付した。特に，No.5は観測期間中において最大の摇れを記録した茨 城県南部を霞源とする地震(M5.4)の発生時刻であり, 屋上の最大加 速度はNS方向で $137.8 \mathrm{~cm} / \mathrm{s}^{2}, \mathrm{EW}$ 方向で $76.4 \mathrm{~cm} / \mathrm{s}^{2}$ であった。ま た, No.2とNo.3は 2004 年新潟県中越地震(M6.8とM6.5), No.8は 2005年宮城県神地震(M7.2)の発生時刻である。

図4-(a)および(b)によれば, 固有振動数の経時デー夕は一定の変 動幅を有しながら，振動数が低くなる方へのスバイクノイズを含ん でいる。これらのスバイクノイズは，15分間の小サンブルデータ内 に地震応答が含まれるために振動振幅依存性によって一時的に低下 する值や，同定時の誤差などが考えられる。

これらスバイクノイズを除去し，固有振動数の日常的な变動を抽 出するため，メジアンフィルタにより同定值の経時デー夕を平滑化 する。ここで，メジアンフィルタとは指定したフィルタ幅(時間空 幅)に含まれるサンブルデータの中央値を選択していく平滑化処理 方法であり，フィル夕幅内に1個しかない桁違いに值が異なるサンプ ル(すなわち，スバイクノイズ）を除去しつつ, 日常的な変動や地震 等による急激な変動を捉えられる点において，一般に広く用いられ る平均值による平滑化処理よりも優れた性能を有する。

図5-(a)および(b)は，図4-(a)および(b)に示した固有振動数の経 時データにメジアンフィルタによる平滑化処理を施した結果であり, フィルタ幅を 75 分とした場合(空幅のサンブル数5個)を灰色線で, 1 日とした場合を黒色線でそれぞれ示す。フィル夕幅を75分とした場 合には, 地震による固有振動数の一時的な低下などのスバイクノイ ズを除去して，日変動などの変動成分を明膫に抽出できる。一方で, フィルタ幅を1日とした場合には，スバイクノイズと日変動をともに 除去して，1日よりも大きな時間スケールの変動のみを抽出できる。

\section{(2)固有振動数の年間変動と環境条件の関係}

固有振動数と環境条件の関保を調べるため, 図6に, 計測期 間内全てで観測データが得られた 3 階 $\mathrm{EW}$ 成分加速度の応答振幅 


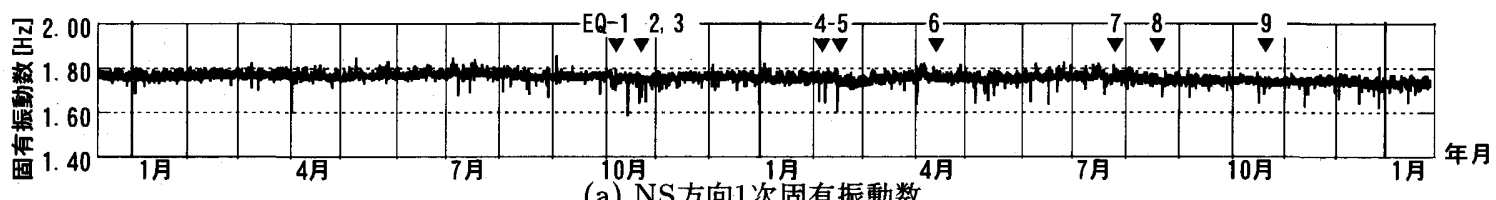

(a) NS方向1次固有振動数

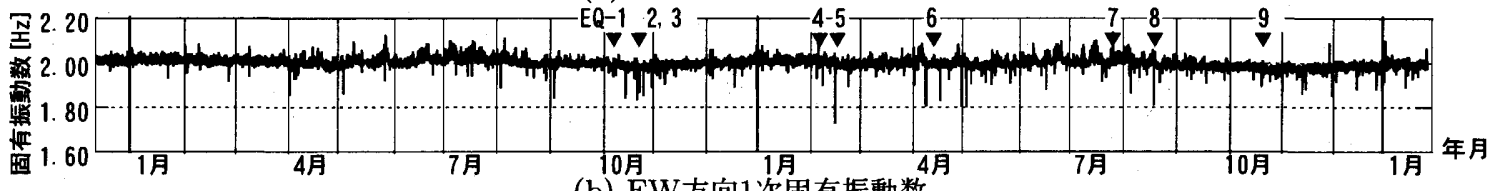

(b) EW方向1次固有振動数

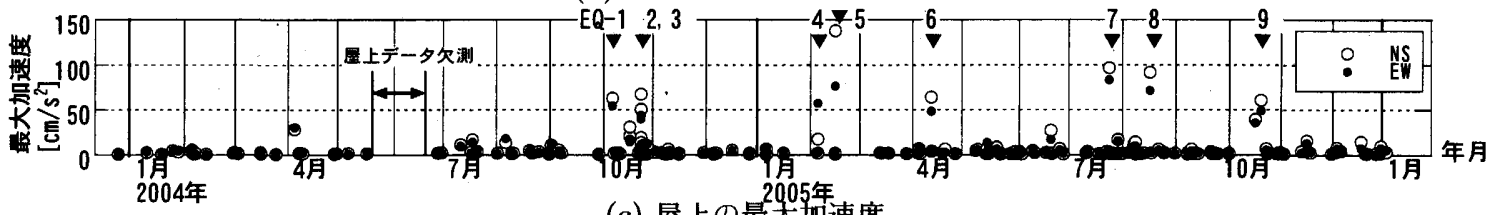

(c) 屋上の最大加速度

図 4 固有振動数の同定値と屋上の最大加速度

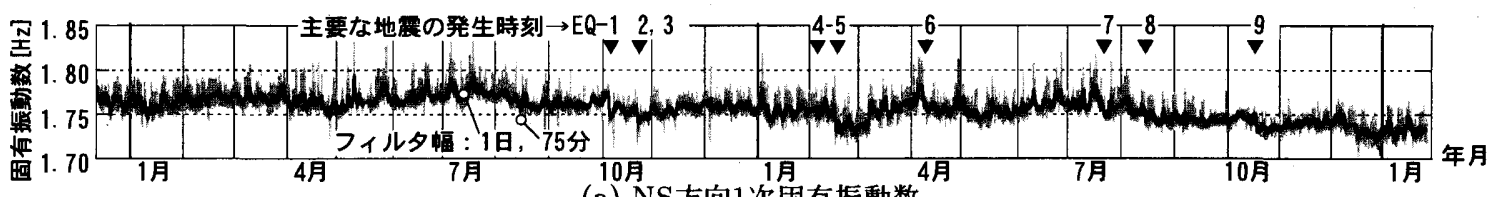

(a) NS方向1次固有振動数

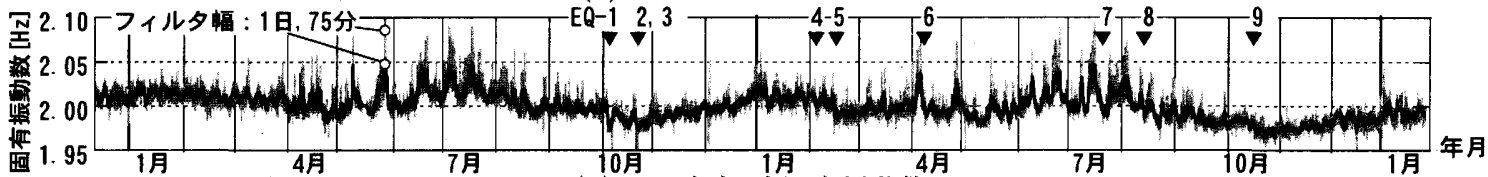

(b) EW方向1次固有振動数

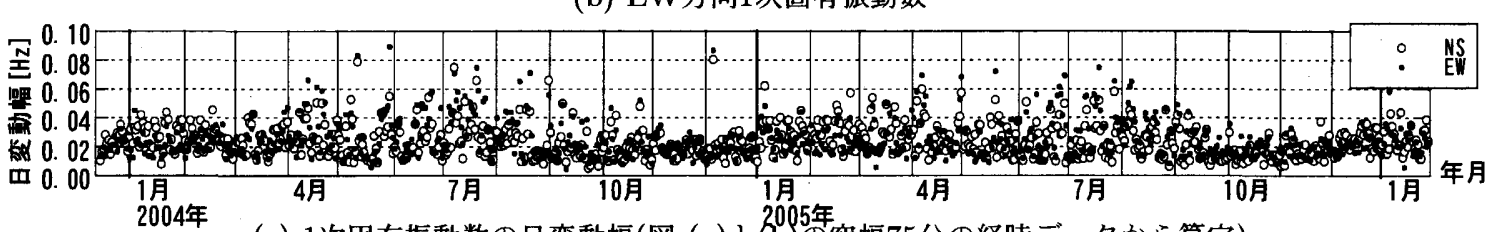

(c) 1次固有振動数の日変動幅(図-(a)と(b) の空幅75分の経時データから算定)

図 52 年間における固有振動数の経時変化(メジアンフィルタ使用)

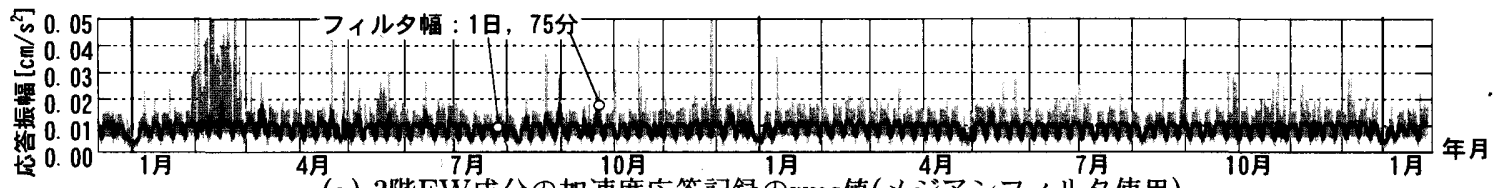

(a) 3階EW成分の加速度応答記録のrms値 (メジアンフィル夕使用)

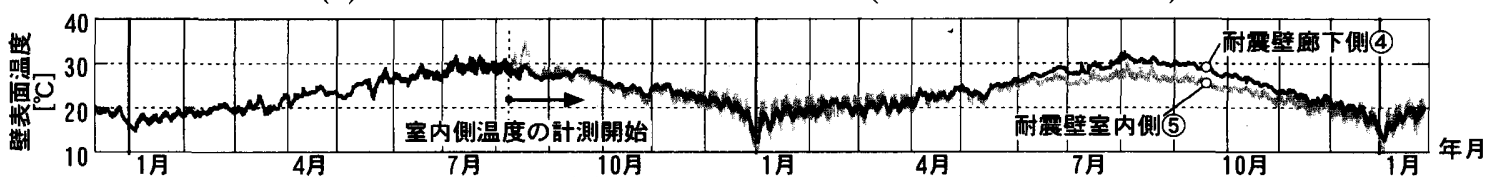

(b) 耐震壁の内側・外側温度

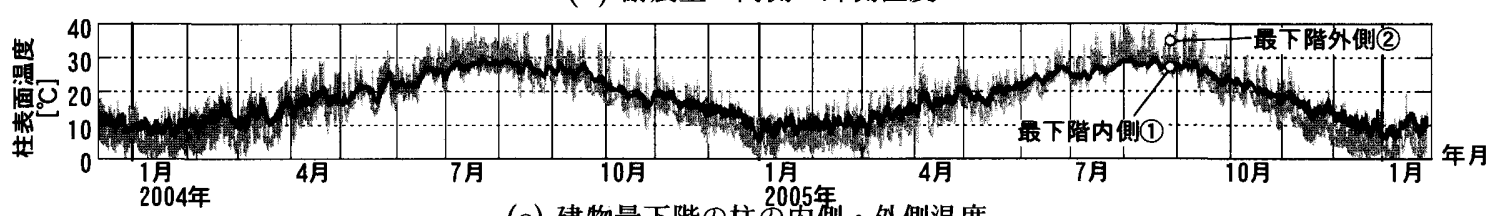

(c) 建物最下階の柱の望側・外側温度

図 62 年間における応答振幅, 建物温度の経時変化

(root-mean-square value)と, 地下3階外周柱および7階耐震壁の 温度を示す。なお，応答振幅はメジアンフィルタによる平滑化後の 結果を示すが，温度については平滑化処理は実施していない。

図5-(a)および(b)によれば，部材温度の上昇時期にあたる5月か
ら7月の間に, フィルタ幅75分と1日のふたつの経時データの差異が 特に大きくなり，この時期に日変動が活発になる傾向が確認できる。 このことを明膫に確認するため, フィル夕幅75分の固有振動数の経 時データから1日の固有振動数の最大値と最小値の差を計算し, その 


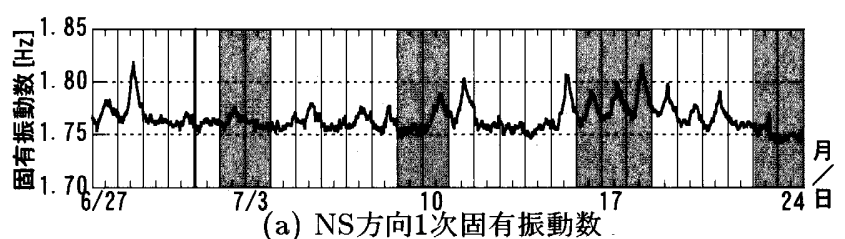

(a) NS方向1次固有振動数

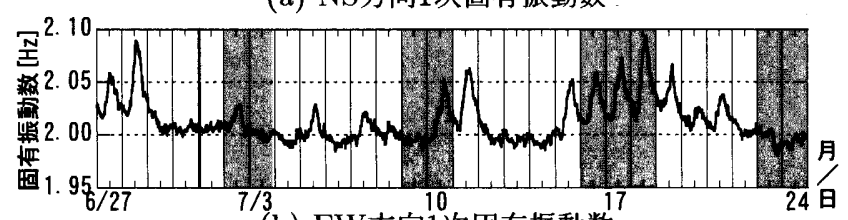

(b) EW方向1次固有振動数

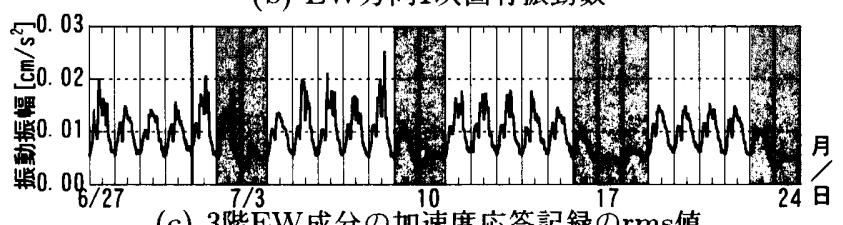

(c) 3 階 $\mathrm{EW}$ 成分の加速度応答記録のrms值

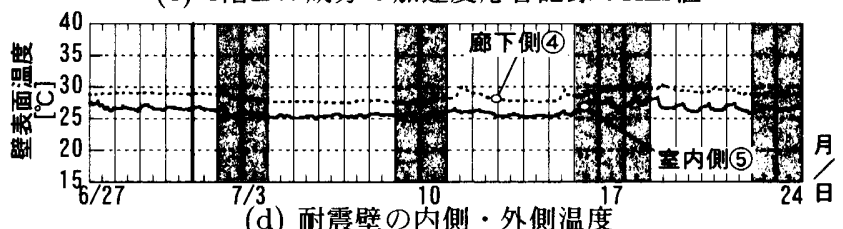

(d) 耐震壁の内側・外側温度

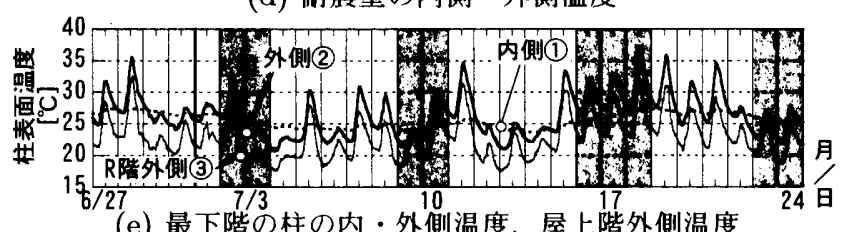

(e) 最下階の柱の内 - 外側温度, 屋上階外側温度

图 7 夏季における固有振動数と応答振幅, 建物温度の経時変化

差を日変動幅とみなして，日変動幅の年間変動を図示した結果を図 5-(c)に示す。この図からは, 固有振動数の日変動が年間を通して発 生していること，図6-(b)および(c)と比較すると，4月〜7月の部材 温度が上昇する時期に日変動が大きくなる日があり，日によって 日変動幅が大きくばらつくこと，これとは対照的に，10月〜12月 の部材温度が下降する時期には日変動が小さくなることが確認で きる。日変動幅の量は年間を通して $0.02 \sim 0.04 \mathrm{~Hz}$ 程度(変動率 $1 \sim$ $2 \%$ 程度)以上は発生している。また，4月〜 7月には，日変動幅が $0.06 \mathrm{~Hz}$ (変動率 $3 \%$ )を超える日もあり, 固有振動数の週単位での変 動も活発になることも確認できる。

一方で，図6-(a)によれば，建物の振動応答は年間を通しておお むね規則正しく変動しており，平日に応答振幅が大きくなり，休日 に応答振幅が小さくなる。特に，年末年始やゴールデンウィーク， お盆休みなどの期間では，応答振幅が小さくなる。また，2004年 2 月付近には建物西側の直近での道路工事による振動によって応答振 幅は通常よりも大きい。これらの応答振幅の年間を通した变動の特 徵は, 固有振動数の経時データには現れていない。

\section{3 固有振動数の日変動に関する考察}

固有振動数の年間デー夕に関する考察によれば，固有振動数の経 時デー夕は部材温度と相関して変動し，その変動の特徵が季節に よって異なる傾向が認められた。本節では, 夏季および冬季の固有 値の経時変化を建物各部材の温度や応答振幅と比較することで, そ れらの相関関係を分析し, 固有振動数の経時変化に日変動が発生す る要因について考察する。
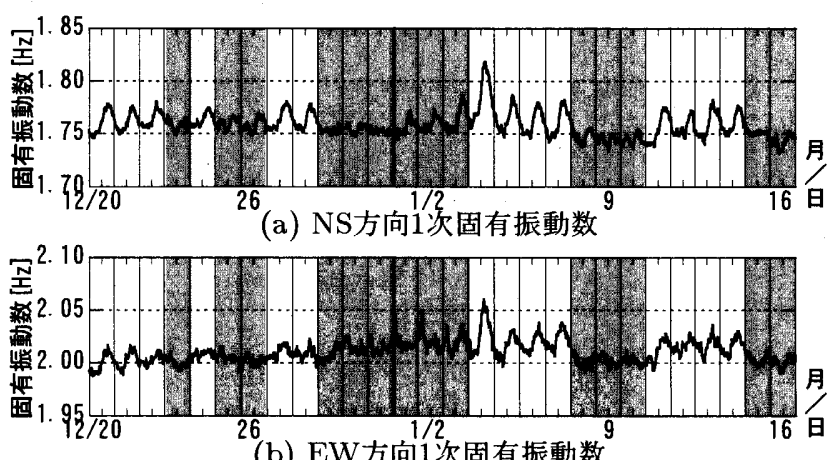

(b) EW方向1次固有振動数

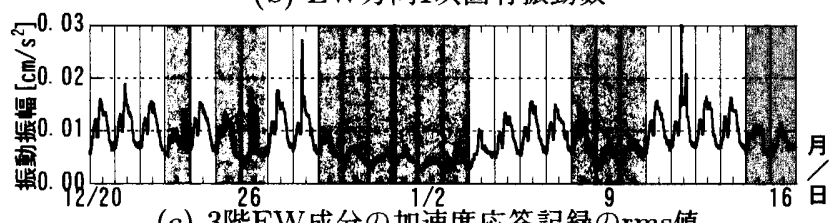

(c) 3 階 EW成分の加速度応答記録のrms値
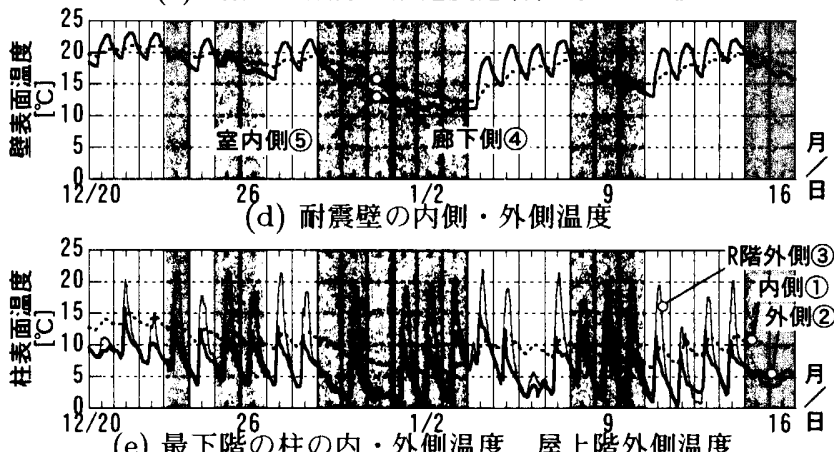

(e) 最下階の柱の内 - 外侧温度, 屋上階外側温度

图 8 冬季における固有振動数と応答振幅, 建物温度の経時変化

\section{(1)夏季における固有振動数の変動}

夏季の固有振動数の経時データの例として, 図7に2005年6月 27 日から7月 24 日までの4週間の測定結果を示す。同図において, 固有 振動数の同定值および応答振幅についてはフィルタ幅75分のメジア ンフィルタで平滑化処理した結果である。また，同図では，時間に 関するグリッドは毎0時を示し，休日(土曜日，日曜日および祝日)に 相当する日を塗りつぶして表示した。

NS方向とEW方向の固有振動数については, 互いに日変動の発 生の傾向が類似している。詳細には，6月27日と28日，7月 2 日，5 日，7日，8日，10日，11日，15日から21日に日変動が現われてい る。これらの日には, 最下階柱の外側温度の日変動が大きく発生し ており, 内側温度を大きく上回っている。その一方で, 耐震壁の室 内側温度や廊下側温度の日変動の振幅は非常に小さく, 固有振動数 の日変動との相関は認められない。また, 応答振幅については, 休 日の日変動がその他の平日よりも小さくなる傾向が認められるが, その傾向は固有振動数には認められない。

\section{(2)冬季における固有振動数の変動}

冬季の固有値の経時変化の例として, 図8に2004年12月 20 日から 2005年1月16日までの4週間の測定結果を示す。期間中において, 12 月 29 日から 1 月 3 日は冬季休腵期間に相当し, 建物内の空調設備はほ ぼ停止状態にあったと思われる。

冬季においても, NS方向とEW方向の固有振動数は, 互いに日 変動の発生の傾向が類似している。詳細には，平日に日変動が現わ れる一方で, 休日に日変動が発生しないか, もしくは日変動の幅が 
表 2 コンクリートの調合結果

\begin{tabular}{|c|c|c|c|c|}
\hline $\begin{array}{c}\text { 圧縮強度 } \\
{[\mathrm{MPa}]}\end{array}$ & $\begin{array}{c}\text { スランブ } \\
{[\mathbf{c m}]}\end{array}$ & $\begin{array}{c}\text { 空気量 } \\
{[\%]}\end{array}$ & $\begin{array}{c}\mathrm{W} / \mathrm{C} \\
{[\%]}\end{array}$ & $\begin{array}{c}\mathrm{S} / \mathrm{a} \\
{[\%]}\end{array}$ \\
\hline 39.0 & 16.5 & 2.5 & 54.2 & 41.5 \\
\hline \hline \multicolumn{5}{|c|}{ 単位量 $\left[\mathrm{kg} / \mathrm{m}^{3}\right]$} \\
\hline $\mathrm{W}$ & $\mathrm{C}$ & $\mathrm{S}$ & $\mathrm{G}$ & $\mathrm{AE}$ 減水材 \\
\hline 179 & 330 & 737 & 1038 & 0.825 \\
\hline
\end{tabular}

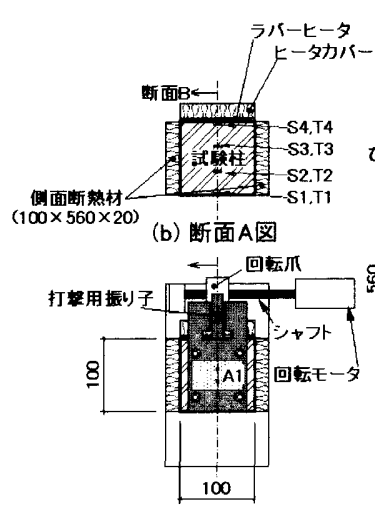

(a) 平面図 (c) 断面 $\mathrm{B}$ 図

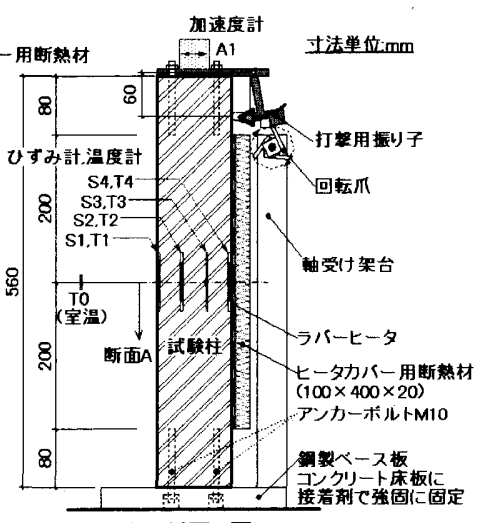

図 9 試験柱の設置状況

小さくなる傾向が認められる。特に, 冬季休暇期間直後の 1 月 4 日の 日変動は非常に大きくなっている。この日変動の傾向は，7階耐震壁 の室内側温度の日変動と類似している。ここで, 7階耐震壁の室内側 と廊下側で温度変化が異なる原因は, 中央コア内部と外部の居室ス ペースの空調方式や使用方法が異なるためである。その一方で，建 物最下階柱および屋上の外面温度の日変動は, 休日と平日の区別な くほぼ毎日発生しており, 固有振動数の日変動との相関は認められ ない。また，応答振幅については休日に日変動が小さくなる傾向は 認められるものの, 土曜日に平日と変わらない日変動を示す日(例え ば12月25日，1月8日)もあり，これらの日は固有振動数の日変動と の相関性があるとはいえない。

\section{5 コンクリート試験柱の熱応カ試験}

\section{1 試験目的}

前節までの実建物の観測結果により，建物の固有振動数には日変 動が認められ，その日変動は部材温度と強い相関関係にあることを 確認した。詳細には, 構造部材の一面の温度が上昇するに伴って固 有振動数は増加する。一般に，コンクリート材料などの固体物質は 加熱によって軟化する傾向にある ${ }^{20)}$ が，この加熱による軟化現象に よって日変動の観測結果を説明することはできない。これに代わる 仮説として，外気温や日照によるコンクリート部材の片面のみの温 度上昇によって温度応力が発生し, その温度応力によってコンク リートのヤング係数が変化するという一連のメカニズムが考えられ る。しかし，筆者の知る限り，それを裏付ける実験デー夕は見当た らない。そこで, 部材レベルでの再現試験を試みた。

\section{2 試験方法}

正方形断面を有するコンクリート試験柱の一側面に温度変動を与 え, 断面内の温度とひずみ, 試験柱の1次固有振動数を断続的に測定 した。試験柱は，サイズ $100 \times 100 \times 560 \mathrm{~mm}$ の無筋コンクリート柱 であり，試験柱の設置状況を図 9 に，コンクリート打設時における調 合結果を表2にそれぞれ示す。

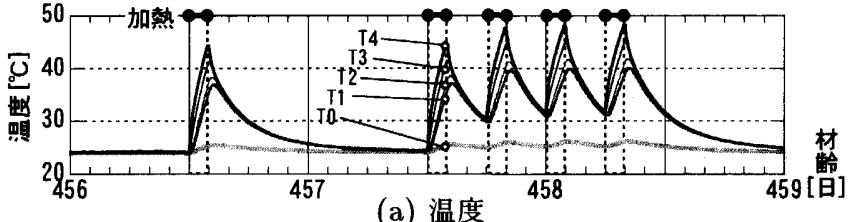

(a) 温度

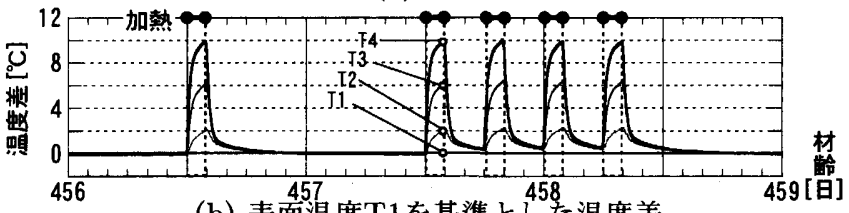

（b）表面温度T1を基準とした温度差

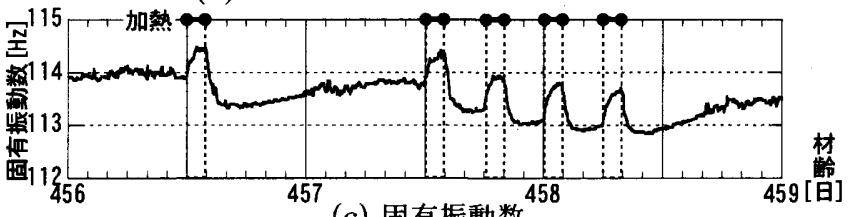

(c) 固有振動数

図 10 試験柱片面を加熱した場合の温度・固有振動数の経時変化

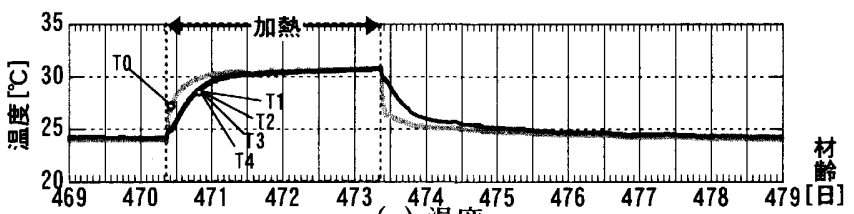
(a) 温度

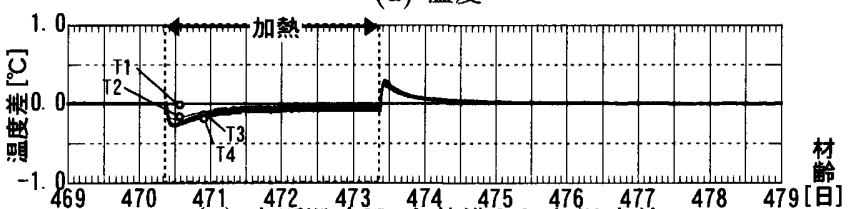

(b) 表面温度 $\mathrm{T} 1$ を基準とした温度差

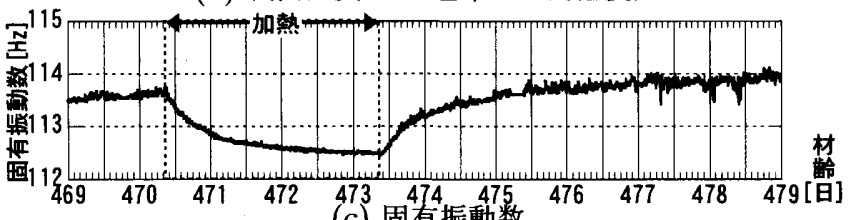

(c) 固有振動数

図 11 試験柱全体を加熱した場合の温度・固有振動数の経時変化

試験柱への加熱は，約 $24^{\circ} \mathrm{C}$ の恒温室に試験柱を設置した上で，側 面に貼付したラバーヒータ $(100 \times 400 \mathrm{~mm})$ にっって行った。ラバー ヒー夕による試験柱断面内の熱伝導をヒー夕面から反対面への一次 元的なものにするため，ヒ一夕面に対して両側面には断熱材 $(100 \times$ $560 \times 20 \mathrm{~mm})$ を貼付した。ラバーヒータによる加熱パターンは，付 与する電圧量の調節（調節後は固定）とタイマーによるON/OFF 制御によって設定した。加熱による試験柱の温度とひずみの経時 データを測定するため, T型熱伝対付きのひずみゲージを試験柱の 中央の高さに断面方向に4点で埋設した。

試験柱の固有振動数は, 頂部に設置した打撃用振り子によって曲 げモ一メントの打撃を試験柱に与え，その際に発生する自由振動応 答に基づいて推定した。打撃用振り子は試験柱に近接して設置され た回転爪によって一定間隔で稼動するようになっており，試験柱へ の打撃の間隔は2分とした。自由振動応答は, 試験柱の頂部に設置し たサーボ型加速度センサによって記録した。試験柱は，ボルト接合 された鋼製ベース盤を介して恒温室のコンクリート床板上に接着剤 で強固に固定されており, 固有振動数の推定值は片端完全固定の曲 
げ梁モデルの1次固有振動数と見なすことができる。

データ収録には, 試験柱の加速度記録を参照するレベルトリガ方 式を採用し，打撃前 3 秒と打撃後 2 秒間の合計 5 秒間の記録をサンブリ ング周波数 $2000 \mathrm{~Hz}$ で収録した。温度とひずみは打撃の影響を受け ていない記録のはじめの1秒間の平均値を測定値とした。一方で，固 有振動数は, 自由振動応答において振幅値が $50 \mathrm{~cm} / \mathrm{s}^{2}$ 以下となった 時点以降の 0.15 秒間の隇衰波形を取り出し, その隇衰波形を自己回 帰モデルに当てはめて同定した。

\section{3 試験結果と加熱と固有振動数の関係に関する考察}

1回の加熱を 2 時間として，加熱してから 2 時間後の表面温度差が $10^{\circ} \mathrm{C}$ に達するようにラバーヒータへの電圧を調整した上で, 1 回の みの加熱のバターンと6時間ごとに4回の加熱を綝り返すバターンか ら構成される加熱試験(合計で5回の加熱)を実施した。この表面温度 差を与えて加熱した場合の試験結果を図10に示す。同図において， 横軸はコンクリート打設時から数えた材齢である。

1回目の加熱開始とともに固有振動数は急激に増加し，表面温度 差の上昇力ーブが飽和する状態と連動するように固有振動数の上昇 カーブも䭒和している。1回目の加熱後の固有振動数は, 加熱停止と ともに急激に値が低下し，加熱前の $114 \mathrm{~Hz}$ よりも低下した後に緩や かに加熱前の值へと回復していく。固有振動数の增加量を加熱直前 の値と加熱中の最大值の差で定義すると，1回月の加熱による増加量 は $0.6 \mathrm{~Hz}$ であり，加熱直前の固有振動数 $114 \mathrm{~Hz}$ を基準とすると増加 率は $0.53 \%$ となる。また，4回の加熱(2回月から5回月)を繰り返した 材齢457.5日以降の固有振動数は, 加熱と加熱停止を繰り返す度に增 加と滅少を繰り返す。2回月から5回月までの固有振動数の增加量を 読み取ると $0.6 \mathrm{~Hz}, \quad 0.6 \mathrm{~Hz} ， 0.7 \mathrm{~Hz} よ ひ ゙ 0.7 \mathrm{~Hz} ゙$ あ，加熱と加熱 停止を繰り返しても增加量おおむね一定しているといえる。一方で, 2 回目から5回目までの加熱期間には, 固有振動数の変動カーブが全 体的に低くなる傾向がみられる。これは加熱によって部材断面の温 度が上昇することによって，コンクリート材料の軟化現象が現れて いるものと思われる。

固有振動数の日変動が表面温度差に起因することを確認するため, 温室内の温度を緩やかに上昇させた後に下降させ，試験柱の断面内 の温度差を極力小さく保持したまま, 試験柱の全断面の温度を上 昇・下降させる試験を実施した。図11はその試験結果であり, 試験 柱の断面内の温度差を $\pm 0.3^{\circ} \mathrm{C}$ 内に保持したまま, 試験柱の温度は 24 ${ }^{\circ} \mathrm{C}$ から31度まで上昇し, 加熱停止後には $24^{\circ} \mathrm{C} に$ 戻っている。このと き, 固有振動数は試験柱の温度変化と連動して, 部材温度が上がる とともに値が減少し, 温度が下がるとともに增加している。この固 有振動数の変化はコンクリート材料の軟化による現象であり, 片面 のみに加熱を繰り返し与えた場合に固有振動数の変動カーブが全体 的に低くなる傾向は同様の現象であると思われる。

以上のように，試験柱の片面のみを加熱あるいは加熱停止するこ とで固有振動数が増加あるいは滅少する傾向が確認され，実建物で 観測された部材温度と固有振動数の相関関係を再現できた。なお, 定量的には, 試験柱の振動数の変動率 $0.53 \%$ は実建物での $3.9 \%$ と比 較して小さいが，これは試験柱の断面寸法が実建物の柱材や耐震壁 と比べて小さく, 温度応力の発生量が小さいために, 固有振動数の 変動幅が小さくなったものと考えられる。

\section{6 結語}

$\mathrm{SRC}$ 造 10 階建物を対象として, 耐震補強工事中の1次固有振動数 を評価した結果, 補強工事の進展に伴い固有振動数が増加する傾向 を大まかに捉えることができたものの, その経時データには日変動 などに起因したばらつきが発生しており，そのばらつきの幅から算 定した変動率はNS方向で $3.9 \%, \mathrm{EW}$ 方向で3.0\%に達した。このば らつきは, 補強工事に伴う固有振動数の增加量を定量的に評価する 上で誤差に相当し, 1層ごとの補強工事による増加率が1.0〜 1.7\%程 度であることを考慮すると無視できない量である。

このばらつきの主な要因である固有振動数の日変動のメカニズム を追求するため, 対象建物の 2 年間にわたる固有振動数の経時デー夕 を分析するとともに，コンクリート試験柱の熱応力試験による再現 実験を試みた。その結果, 対象建物に関しては, 固有振動数の日変 動は季節によって発生の傾向が異なるものの年間を通して発生して いること，その日変動は夏季には外周柱内外面の温度差と相関し， 冬季には中央コア部分の耐震壁の表面温度差と相関する傾向がある こと, 構造部材の片側の温度が上昇するとともに固有振動数が増加 する傾向にあることなどを明らかにした。また，コンクリート試験 柱の熱応力試験の結果からは, 表面温度差の発生に伴って固有振動 数が増加する傾向が確認され, 対象建物での固有振動数と部材温度 の関係を再現することができた。以上の結果から，対象建物の固有 振動数に日変動が発生するメカニズムは, 表面温度差の発生に伴っ てコンクリート部材の佣性が增加したため, 建物全体の固有振動数 が増加するという一連の仕組みが考えられる。

本研究で得られた固有振動数の日変動の発生メカニズムを考慮し て, 固有振動数と部材温度の定量的な関係を導くことで, 固有振動数 の経時データから日変動を除去できれば，固有振動数などの振動特性 を指標とした精度の高い構造ヘルスモニタリング技術が確立できる可 能性がある。また, 固有振動数と部材温度の関係はコンクリート構 造部材への損傷の有無によって異なる可能性が強く, 固有振動数の 日変動を積極的に利用した構造ヘルスモニタリングへの応用も考え られる。これらの研究については稿を改めて論じることにしたい。

\section{謝辞}

本研究の遂行にあたり，文部科学省科学研究費補助金若手研究 (B)「RC造建築物を対象とした固有周期の日変動メカニズムの解 明と早期劣化診断への応用」（課題番号:16760467）の助成を受け た。また，コンクリート試験柱の製作に際して，(財)電力中央研究 所の松村卓郎博士の指導を受けた。

\section{参考文献}

1) Housner, G.W., et al.: Special issue: Structural control: Past, present, and future, Jour. of Eng. Mech., ACSE, Vol.123, No.9, 1997.9

2) Rens, K.L., T.J. Wipf, F.W. Klaiber: Review of nondestructive evaluation technique of civil infrastructure, Journal of Performance Constructed Facilities, ASCE, Vol.11, No.4, 1997.

3）山本鎮男: ヘルスモニタリングー機械・ブラント・建築・土木構造物・医瘵の 健全性監視，共立出版，1999

4) 阿部良洋：鉄筋コンクリート造建物の微振動特性と耐震性能に関する研究，東 北大学博士学位論文, 1988 .

5）大場新太郎，濱川尚子：1995年兵庫県南部地震における杭の損傷による建物固有 周期の変化，日本建築学会構造系論文報告集，第495号, pp. 63-70, 1997.5.

6) 例えば, 濱本卓司, 森田高市, 相馬澄子: 逐次最小二乗法による多首建築物の地 
震損傷追跡，日本建築学会構造系論文報告集，第603号，pp. 39-46，2006.5

7）例元ば, 日本建築学会編：建筑物の減言, pp. 160-176, 2000

8）金澤健司，小川浄，矢花修，宮住勝彦：超高鉄筋コンクリート造煙突の振動特 性の日変動, 日本建築学会構造系論文報告集，第568号，pp. 67-72, 2003.6.

9) 岡田将敏, 金澤健司, 矢花修一: 超高RC造煙突の固有振動数と壁面温度の相 関性, 日本建筑学会学術講演概要集，構造II(B-2)，pp. 417-418，2005.9.

10）金澤健司: SRC造建築物の固有振動数の日変動, 日本建築学会学術講演概要 集，構造II(B-2)，pp. 845-846，2003.9.

11) Clinton, J.F., Bradford, S.C., Heaton, T.H. and Favela, J.: The observed wander of the natural frequencies in a structure, Bulletin of the Seismological Society of America, Vol.96, No.1, pp. 237$257,2006.2$.

12) Askegaard, V. and P. Mossing: Long term observation of RCbridge using changes in natural frequency, Nordic Concrete Research 7, pp. 20-27, 1988

13) Farrar, C.R., S.W. Doebling, P.J. Cornwell, E.G. Straser: Variability of modal parameters measured on the Alamosa Canyon Bridge, Proc. of the 15th International Modal Analysis Conference, Orlando,FL., pp. 20-27, 1997.2.
14) Petters, B. and De Roeck, G.: One year monitoring of the Z24Bridge: environmental effects versus damage events, Earthquake Engineering and Structural Dynamics, Vol.30, Issue 2, pp. 149$171,2001.2$.

15) Safak E. and Hudnut K.: Real-time structural monitoring and damage detection by acceleration and GPS sensors, Proc. of the 8th U.S. National Conference on Earthquake Engineering, Paper No. 1005, 2006.4.

16) 金澤健司: ARMAMAモデルによる振動モード同定法の常時微動記録への適 用, 第11回地震工学シンポジウム論文集，pp.1885-1890，2002.11

17）金澤健司、松井徹哉: ARMAMAモデルによるスペクトル解析と振動モード 同定，日本建筑学会構造系論文集，第554号，2002.4

18) K.Kanazawa and K.Hirata: Parametric estimation of the cross power spectrum density, Jounral of Sound and Vibration, Vol 282, No. 1, pp. 1-35, 2005.

19）中村充，安井榉：微動測定に基づく地霞被災鉄骨建物の層損傷評価，日本建築 学会構造系論文報告集, 第517号, pp. 61-68, 1999.3.

20）例えば，Schneider，U.(森永繁活か訳)：コンクリートの熱的性質，pp.75-79, 技報堂出版，1983.12.

（2006年 7 月 6 日原稿受理，2006年10月19日採用決定） 